Review

\title{
The Effect of Immunosuppressive Drugs on MMPs Activity in The Walls of Blood Vessels - A Systematic Review
}

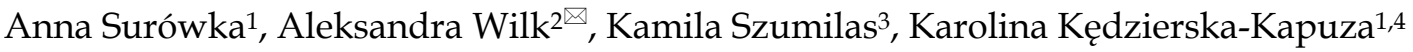 \\ 1. Department of Nephrology, Transplantology and Internal Medicine, Pomeranian Medical University, 70-111 Szczecin, Poland. \\ 2. Department of Histology and Embryology, Pomeranian Medical University, 70-111 Szczecin, Poland. \\ 3. Department of Physiology, Pomeranian Medical University, 70-111 Szczecin, Poland. \\ 4. Clinical Department of Gastroenterological Surgery and Transplantation, Central Clinical Hospital of the MSWiA in Warsaw, Poland. \\ $\square$ Corresponding author: Aleksandra Wilk, Department of Histology and Embryology, Pomeranian Medical University, 70-111 Szczecin, Poland; E-mail: \\ aleksandra.wilk@pum.edu.pl; Phone no: 0048502043488
}

(c) The author(s). This is an open access article distributed under the terms of the Creative Commons Attribution License (https://creativecommons.org/licenses/by/4.0/). See http://ivyspring.com/terms for full terms and conditions.

Received: 2020.10.13; Accepted: 2020.12.18; Published: 2021.01.30

\begin{abstract}
The current study focuses on the role of MMPs in the pathogenesis of the vascular damage and at the same time it offers the review referring to the influence of the immunosuppressive treatment on this interdependence. Contemporary immunosuppressive treatment constitutes of four groups of medications, such as: calcineurin inhibitors including cyclosporine $A$ and tacrolimus; inhibitors of the inosine monophosphate dehydrogenase - the only agent from this group currently used in transplantation is mycophenalate mofetil (MMF); mTOR inhibitors, consisting of everolimus and glucocorticosteroids. Due to the fact that the properties of immunosuppressive drugs still remain unclear and transplant recipients need to use these medicines every day, knowledge of this should be further expanded. The deceases of the patients with the functioning graft who were diagnosed with the cardiovascular system diseases, constitute $50 \%$ of all renal transplant recipients. Immunosuppressive treatment leads to many pathological alterations within the organs and tissues and additionally they undoubtedly affect the activity of MMPs in the wall of the vessels.
\end{abstract}

Key words: immunosuppressive drugs, metalloproteinases, inhibitors, extracellular matrix.

\section{Introduction}

Nowadays, organ transplantations are being carried out increasingly often. Following the transplantation procedure, patients take immunosuppressive agents which prevent transplant organ rejection. Contemporary immunosuppressive treatment constitutes of 4 groups of medications, such as: calcineurin inhibitors (CNIs) including cyclosporine A (CsA) and tacrolimus (TAC); inhibitors of the inosine monophosphate dehydrogenase (IMDH inhibitors) - the only agent from this group currently used in transplantation is mycophenalate mofetil (MMF); mTOR inhibitors (mTORIs), consisting of everolimus and glucocorticosteroids (GCS) [1]. On one hand, immunosuppressive agents lower immunity, on the other hand, they display toxic impact on the organs
[2-7]. Furthermore, they can lead to pathological changes within the vessels $[8,9]$. The dysfunction of the endothelium is currently regarded as one of the dominant aspects of vessel change development. Recently, increase of interest in the influence of immunosuppressive treatment on the disorder of cardiovascular system is clearly observed, with the particular focus on the role of vessel endopeptidases. Chronic graft dysfunction (with both immunological and non-immunological background) accounts for $50 \%$ of the organ rejections, whereas the deceases of the patients with the functioning graft who were diagnosed with the cardiovascular system diseases, infections or tumors constitute the other half [10].

The cascade of the ongoing processes is mediated by means of the metalloproteinases 
(MMPs). Metalloproteinases have significant role in the transformation and functioning of the extracellular matrix of numerous tissues and organism structures. The current study focuses on the role of MMPs in the pathogenesis of the vascular damage and at the same time it offers the review referring to the influence of the immunosuppressive treatment on this interdependence.

\section{Metalloproteinases}

Extracellular matrix (ECM) is a multi-component solid structure which fills the space between the cells. It consists of the ground substance and fibers. The ground substance is an amorphous substance which binds significant amounts of water. Apart from the glycosaminoglycans and proteoglycans, it comprises glycoproteins suspended in the polysaccharide solution, which gives the function of ideal framework for the tissues as well as safe environment for the maturing cells. Extracellular matrix is also a very active structure, subject to constant changes and transformations, simultaneously controlling and modulating the signals reaching the cells [11].

Dynamically transforming ECM structure plays significant role both in proper functioning of the tissues as well as in the pathomechanism of various organ ailments, including pathogenesis of the cardiovascular system diseases. The fundamental role in the pathological transformation of extracellular components, in the vascular remodeling as well as in the migration and proliferation of cells, is attributed to the malfunctions of metalloproteinases (MMP) and metalloproteinases inhibitors (TIMPs) [12-14].

Matrix metalloproteinases (MMPs) are structurally similar to endopeptidases whose activity impacts the structure of ECM proteins and connective tissue. Their proteolytic activity is not limited to the transformation of extracellular sphere of tissues. Dissecting numerous proteins, they contribute to the degradation of receptors on the cellular surface creating peptide fragments which bind numerous mediators. Through the protein hydrolysis they modulate activity and concentration of growth factors and cytokines. The purpose of their activity is to create the space which enables migration of cells and proper regulation of matrix-cell and cell-cell interactions as well as the arrangement of matrix structure [15-18]. It plays significant role in many physiological processes, including embryogenesis, angiogenesis, remodeling of vessels. Keeping proper balance between the processes of degradation and synthesis of extracellular matrix components constitutes the basic requirement for maintaining tissue balance. Uncontrolled increase of MMP expression and activity is the characteristic component for the ongoing alterations with the pathological background [16, 19-21].

MMPs classification is primarily based on their activity, various substrate specifics enabled the classification of various endopeptidases to one of the six distinguished groups: collagenase - MMP-1, MMP-8, MMP-13; gelatinase - MMP-2, MMP-9; stromielisin - MMP-3, MMP-10, MMP-11; matrilisin MMP-7, MMP-26; membrane type metalloproteinases - MMP-14, MMP-15, MMP-16, MMP-17, MMP-24, MMP-25; non-classified metalloproteinases - MMP-12, MMP-19, MMP-20, MMP-21, MMP-23 [16, 22-24]. Classification is also based on the difference in the protein quaternary structure, however general structure pattern is homologous for all metalloproteinases. Configuration of these molecules consists of three domains: n-terminal domain built of signaling peptides (separated after translation), propeptid, catalytic domain with the active spot and C-terminal domain [24].

In majority, MMPs are released to the extracellular space in the form of the inactive proenzymes- zymogens. N-terminal domain is in charge of maintaining enzyme in this form. Cysteine, which is included in the propeptid, binds with zinc atom in the active site of the catalytic domain by thiol groups. The whole entity is stabilized by three molecules of histidine in the active site. The first stage of the metalloproteinase activation involves cysteine separation from N-terminal domain and ultimate separation of propeptide from MMP. The final hemopexin domain is located on the C-terminal end. It also takes part in the endopeptidase mobilization, and due to the inhibitors adding capacity, it impacts inhibition of the process $[15,16,25-28]$.

\section{Regulation of MMPs expression and activity}

Inhibition of active enzymes is carried out by means of nonspecific ( $\alpha-2$ macroglobulin and a1antitrypsin) and specific inhibitors. Four endogenous metalloproteinases inhibitors (TIMPs) - TIMP-1, TIMP-2, TIMP-3, TIMP-4 belong to the latter group [29]. They display various affinity in reference to MMPs. Similarly to endopeptidases, these proteins consist of domains. Due to C-end domain they connect with metalloproteinases in 1:1 ratio. This inhibition form is a reversible process [26, 30-33]. Metalloproteinases activation may be also controlled in the gene transcription stage, zymogenes release and proenzymes activation. This stimulation is activated under the influence of various factors activity, i.e. cytokines (IL-1, IL-6), growth factors (EGF, FGF, VEGF, PDGF, HGF), tumor necrosis factors (TNF- $\alpha$, TNF- $\beta$ ), antigens (CD40), free radicals, 
plasmines, trombines, urokinase, nitrogen oxide [34-38].

In the physiological conditions, endothelial cells and smooth muscle cells control release of MMPs and TIMPs on the constant level. It enables to keep the balance between degradation and synthesis of the blood vessel wall elements. The histological structure of the wall of muscular artery was presented in Figure 1. Each type of endothelium damage results in the activation of the inflammatory cascade and the adhesion of the monocytes and macrophages to the vessel wall results in the violation of stability and the uncontrolled increase of MMPs activity [31, 39, 40]. Additionally, the activity of endopeptidases is strengthened by constant growth of the proinflammatory cytokines, tumor necrosis factors or oxidized lipoproteins with low density. The activity of metalloproteinases itself is based on setting the path for the inflammatory cells, destruction of the extracellular matrix proteins as well as stimulation and proliferation of smooth muscles cells [39, 41].

It has been confirmed that gelatinases (MMP-2, MMP-9) influence the development of atherosclerotic plaque and, moreover, they influence the origination of aneurysms. Expression of the remaining peptidases varies according to the kind and structure of the vascular lesions. Nevertheless, infiltration from the inflammatory cells and increased expression of the relevant MMPs constitute progression markers of the atherosclerotic plaque and the indicators of its instability [39, 41-43]. This interdependence is the reason of current increase of interest in metalloproteinases as the prognostic factors in course of cardio-vascular diseases.

\section{Clinical significance of metalloproteinases in the vascular diseases}

Distinct increase of MMP-1, -2, -3, -8, -9, -10, -11, $-12,-13,-14,-16$ activity can be diagnosed within atherosclerotic changes [42, 44]. According to the aforementioned, the dominance of individual peptidases differs according to the structure of the atherosclerotic plaque. In case of the fibrous changes, MMP-1, MMP-3 and MP-9 dominate but the changes rich in lipids are characterized by increased levels of MMP-1, MMP-8, MMP-12, MMP-12, MMP-16 [42, 44]. Clinical significance of the metalloproteinases in the vascular diseases aims to show the correlation between excessive activity of individual peptidases in the blood serum and prove their connection with the patient's disease condition.

The table below presents the summary of the research carried out so far on the potential increase of MMPs in the selected vascular diseases (Table 1).

Table 1. Individual MMP activity in the disease entities.

\begin{tabular}{lll}
\hline Disease entity & Increase of enzyme & Reference \\
\hline Coronary heart disease & MMP-1, MMP-2, MMP-8, & {$[45-47]$} \\
& MMP-9 & \\
Unstable coronary heart disease & MMP-1, MMP-2, MMP-9, & {$[45,46,48$,} \\
& MMP-3 & $49]$ \\
Arterial hypertension & MMP-1, MMP-9, TIMP-1 & {$[50-52]$} \\
$\begin{array}{l}\text { Aorta aneurysm } \\
\begin{array}{l}\text { Atherosclerosis of the peripheral } \\
\text { vessels }\end{array}\end{array}$ & MMP-3, MMP-9 & {$[46,53,54]$} \\
\hline
\end{tabular}

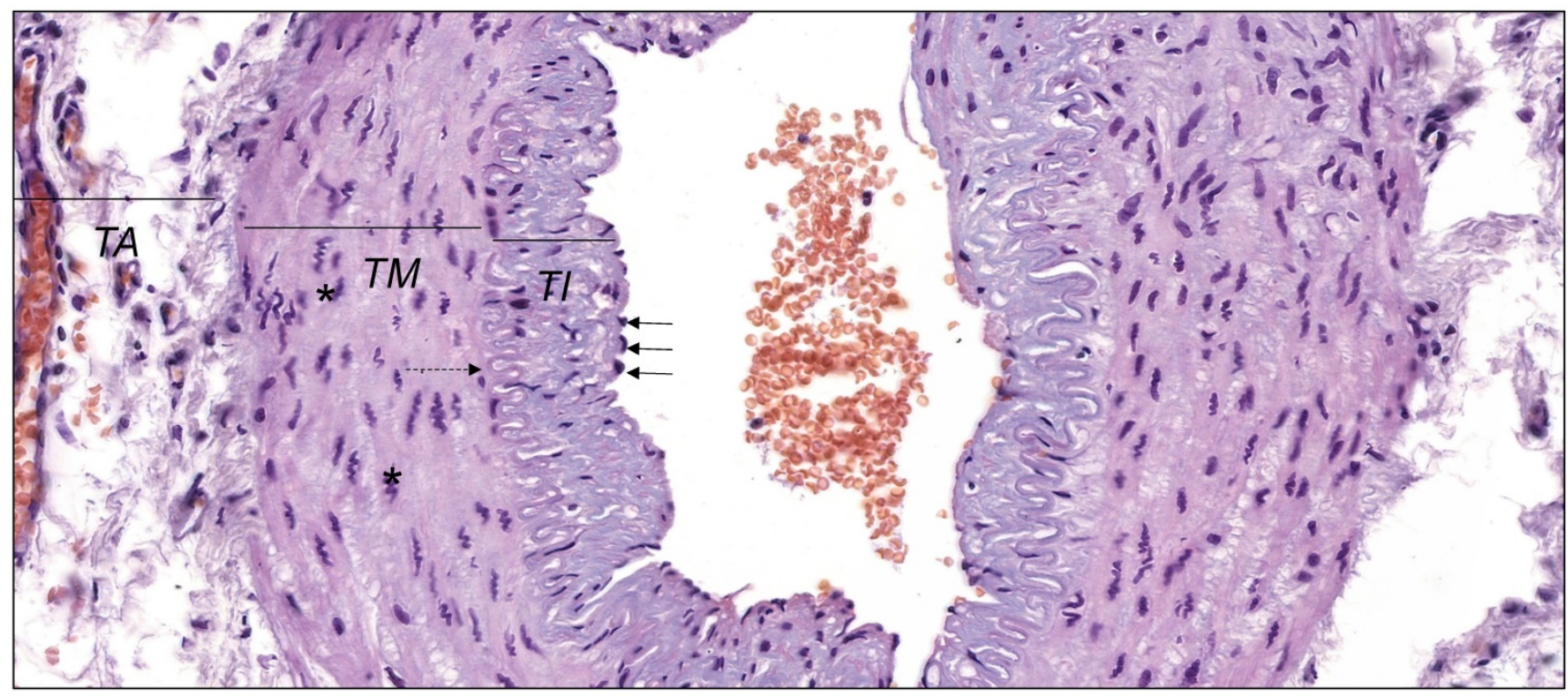

Figure 1. The wall of muscular artery presenting tunica intima (TI) lined with endothelium with nuclei of endothelial cells (black arrows), tunica media (TM) with nuclei of vascular smooth muscle cells $\left(^{*}\right)$ and tunica adventitia (TA). Between TI and TM internal elastic lamina is visible (dashed arrow). Hematoxylin and eosin staining (objective magnification, $\times 40$ ). Original photography by Aleksandra Wilk, Department of Histology and Embryology, Pomeranian Medical University in Szczecin, Poland. 
Table 2. Influence of immunosuppressants on MMPs activity

\begin{tabular}{|c|c|c|c|c|c|}
\hline Drug & Metalloproteinases activities & Examined material & Comments & References & Country \\
\hline \multicolumn{6}{|c|}{ Calcineurin Inhibitors } \\
\hline \multirow[t]{4}{*}{ Cyclosporine } & $\begin{array}{l}\text { Increased activity of MMP-1, MMP-3, MMP-8, } \\
\text { MMP-9 and MMP-13, decreased activity of MMP2 }\end{array}$ & $\begin{array}{l}\text { Endothelial cells of } \\
\text { human umbilical vein }\end{array}$ & $\begin{array}{l}\text { Tests carried out on the umbilical vein } \\
\text { endothelial cells }\end{array}$ & {$[60]$} & Korea \\
\hline & Inhibition of activity of MMP-2, MMP-9, TIMP-1, & Carotid arteries of rats & $\begin{array}{l}\text { Local thickening of the endothelium. Increased } \\
\text { depositing of ECM in the vascular } \\
\text { endothelium }\end{array}$ & {$[61]$} & UK \\
\hline & $\begin{array}{l}\text { Increase of MMP2 activity and expression } \\
\text { following renal ischemia- reperfusion and } \\
\text { treatment with cyclosporine }\end{array}$ & Kidneys of rats & Progression of lumen of the vessel narrowing & {$[63]$} & France \\
\hline & $\begin{array}{l}\text { MMP2 level increase, constant levels of MMP-1, } \\
\text { MMP-9 }\end{array}$ & Myocardium of rats & $\begin{array}{l}\text { Degenerative changes with the fibrosis of } \\
\text { myocardium and increase of } \\
\text { MMP2 and VEGF. }\end{array}$ & {$[62]$} & Italy \\
\hline \multirow[t]{4}{*}{ Tacrolimus } & Inhibition of activity of MMP-2, MMP-9, TIMP-1, & Carotid arteries of rats & $\begin{array}{l}\text { No effect on the local thickening of the } \\
\text { endothelium. Increased depositing of ECM in } \\
\text { the inner layer of the vessel. }\end{array}$ & {$[61]$} & UK \\
\hline & $\begin{array}{l}\text { Expression of Informational RNA (mRNA) for } \\
\text { collage III and TIMP-1was significantly lower } \\
\text { among the patients who were given tacrolimus } \\
\text { than among the patients treated with cyclosporine. }\end{array}$ & $\begin{array}{l}\text { Renal biopsies from the } \\
\text { post-transplant } \\
\text { patients }\end{array}$ & - & [65] & UK \\
\hline & $\begin{array}{l}\text { Intrarenal expression of MMP-2, TIMP- } 2 \text { increased } \\
\text { among the patients treated with tacrolimus in } \\
\text { comparison to the patients treated with } \\
\text { cyclosporine. }\end{array}$ & Renal biopsies & $\begin{array}{l}\text { Renal biopsies from the patients with the } \\
\text { histologically diagnosed CsA or Tac } \\
\text { nephrotoxicity } \\
\text { CsA or Tac and acute rejection. }\end{array}$ & {$[66]$} & USA \\
\hline & $\begin{array}{l}\text { Expression of MMP- } 2 \text { and MMP-9 remained } \\
\text { unchanged by tacrolimus, TIMP- } 1 \text { expression was } \\
\text { lowered. }\end{array}$ & Rats kidneys & $\begin{array}{l}\text { Test results suggest that pirfenidone may } \\
\text { additionally lower fibrosis potential of } \\
\text { tacrolimus }\end{array}$ & [67] & UK \\
\hline \multicolumn{6}{|c|}{ mTOR inhibitors } \\
\hline \multirow[t]{4}{*}{ Rapamycin } & Inhibiting the activity of MMP-2, MMP-9, TIMP-1, & Rats carotid & $\begin{array}{l}\text { Decrease of the endothelium local thickening. } \\
\text { Increased depositing of ECM depositing in the } \\
\text { inner layer of the vessel. Decreasing the } \\
\text { progression of vessel narrowing. }\end{array}$ & {$[61]$} & UK \\
\hline & Inhibiting the release of MMP-2, MMP-9. & $\begin{array}{l}\text { The endothelium cells } \\
\text { of the human umbilical } \\
\text { vein }\end{array}$ & $\begin{array}{l}\text { Tests carried out on the human pathway of the } \\
\text { endothelium cells of the umbilical vein } \\
\text { EA.hy } 926 \text {. inhibition of cellular migration and } \\
\text { degradation of the extracellular matrix. } \\
\text { Profibrotic activity. }\end{array}$ & {$[68]$} & China \\
\hline & Inhibiting activity of MMP-9 & $\begin{array}{l}\text { Experimentally } \\
\text { developed renal artery } \\
\text { aneurysms in rats }\end{array}$ & $\begin{array}{l}\text { Decreased progression of aneurism following } \\
\text { rapamycin application }\end{array}$ & {$[70]$} & USA \\
\hline & Inhibiting activity of MMP-2, MMP-9, TIMP-1 & $\begin{array}{l}\text { Allogenic } \\
\text { transplantations of } \\
\text { rats' thoracic aorta }\end{array}$ & - & [69] & UK \\
\hline
\end{tabular}

\section{Immunosuppressive agents influence on MMPs activity in the blood vessels}

This part of review describes the influence of immunosuppressive drugs with the division on calcineurin inhibitors and mTORs on MMPs activity in the wall of the blood vessels. Additionally, the summary of is presented in Table 2 .

\section{Calcineurin inhibitors}

Calcineurin is the protein that exhibits serine-threonine phosphatase activity. The most significant function of this enzyme is the transfer of signals in the path leading to the activation of the T-lymphocytes [56]. In order to show its role in the functioning of the immunological system, it is necessary to explain shortly the structure and activity of this protein. Calcineurin is composed of two major sub-units: calcineurin A with the catalytic function to bind calmodulin, and calcineurin B- regulatory entity connecting calcium. The recognition of antigen by the T-cell receptors, through the activity of phospholipase $\mathrm{C}$ and inositol triphosphate, leads to the increase of cytoplasmatic concentration of calcium in the cell [6]. Calcineurin-calmodulin-calcium complex originates, which activates calcineurin. Subsequently, calcineurin influences expression of relevant genes by dephosphorylation of nuclear factors of the activated T-cells (NFATc) $[9,57]$. Dephosphorylated forms of enzymes migrate from the cytoplasm to cell nucleus where they lead to, inter alia, increase of gene transcription for IL-2, IL-3, IL-4 and tumor necrosis factor (TNF- $\alpha)$. Created cytokines stimulate proliferation and differentiation of leukocytes. Calcineurin inhibitors act by stopping the described sequence. Due to the strong immunosuppressive activity they are a standard practice in the treatment process following the organ transplantation, which is highly effective in the prevention of the graft rejection. Moreover, they display numerous negative symptoms, inter alia, adverse effect on the 
cardio-vascular system $[9,58]$. Cyclosporin A (CsA) and Tacrolimus (Tac) belong to the calcineurin inhibitors group of medicaments.

Immunosuppressive activity of CsA is based on binding calcineurin with cyclophilin. It prevents dephosphorylation NFATc and thereby its translocation to nucleus and gene transcription to, inter alia, IL-2 [6, 59]. CsA also blocks signaling pathways activating T-lymphocytes, to a lesser extent it influences the inhibition of antibodies production and reduction of mobilization of macrophages [4]. Apart from the influence on the immunological system, this medicament demonstrates a number of adverse effects, including acute and chronic nephrotoxicity and arterial hypertension. These complications result from the damage to the vessel [2, $5,6,59]$.

The researches carried out using human umbilical vein endothelium cells (HUVECs) demonstrated increase of MMPs activity in the cytoplasm. Isolated HUVECs cells were put on the platelets and incubated with cyclosporin. The results of this study may suggest adverse effect of CsA on the vessel structure by the violation of balance of the specific endopeptidases: activity increase of MMP-1, MMP-3, MMP-8, MMP-9, MMP-13 and activity decrease of MMP-2 [60]. Furthermore, research carried out on the rats arteries demonstrates more extensively the influence of CsA on the vessel's wall. The animals which underwent balloon angioplasty of the common carotid artery were given cyclosporine. Spot thickening of the endothelium connected with the increased depositing of ECM components was observed among the animals treated with CsA, and in consequence vessel lumen was narrowed. MMP-2, MMP-9 and TIMP-1 expression was lowered in comparison to the control group, however the ratio MMP-2:TIMP-1 and MMP-9:TIMP-1 was increased in both cases [61]. Moreover, myocardium is also subjected to the adverse influence of CsA. In the cardiac muscle tissue of rats which underwent the treatment several degenerative changes accompanied with fibrosis were observed. MMP-2 level increase was accompanied with the increase of vessel endothelium growth factor- VEGF. The authors suggest that both proteins are the response against excessive amount of collagen and ischemic episodes resulting from CsA toxic activity. The response of the myocardium to the excessive growth of ECM is the increased enzymatic response [62].

Regarding CsA, recent studies report positive influence of the mesenchymal stem cells (MSCs) on the improvement of the activity of the kidney subjected to the ischemic-reperfusion operation and subsequent therapy using CsA. Ischemia-reperfusion model of kidney was obtained in rats subjected to unilateral nephrectomy. Then, for the period of 28 days, the animals were given CsA. MSCs was injected directly to the kidney for 7 days after ischemic-reperfusion operation. Interestingly, the effect of giving mesenchymal cells was connected with the decrease of infrestitial fibrosis, improved activity of kidneys and lower activity of MMP-2 in comparison with organs which underwent immunosuppressive treatment only. In summary, applying MSC may be connected with the protective influence on the organ subjected to stressful factors such as ischemia or toxic effect of CsA [63].

Tacrolimus is the second important representative from the group of calcineurin inhibitors. Contrary to CsA connected with cyclophilin, this drug interacts with the protein binding tacrolimus- FKBP. Immunosuppressive mechanism remains similar, it prevents dephosphorylation of the transcriptive factors and, in consequence, cytokine expression and cascade stimulating proliferation and T-lymphocyte activity is inhibited [59, 64].

Comparison of the influence of immunosuppressants on the expansion of intima membrane among rats subjected to the balloon angioplasty of the carotid artery, tacrolimus (in contrast to CsA) did not result in the thickening of the intima membrane of the vessel. At the same time, it inhibited expression of MMP-2, MMp-9 and TIMP-1. The violation of balance of metalloproteinases release reflected in the increased depositing of ECM components within the vessel wall [61]. In the study presenting diverse influence of cyclosporin and tacrolimus on the gene expression associated with the fibrosis in the isolated renal glomeruli of the kidney recipients higher profibrotic activity of CsA than Tac was also observed. Extracellular matrix was constantly remodeled. The balance between synthesis and degradation of its components may have been maintained by the action of MMPs. Increase of TIMP release supports excessive expansion of ECM. Increased mRNA level for collagen III and TIMP-1 in comparison CsA was observed among the patients treated with Tac, however no disparity was reported in the expression of MMP-2 and TIMP-2 between the tested groups [65]. Additionally, expression level of profibrotic genes among the patients with cyclosporine- or tacrolimus- induced nephrotoxicity was higher among the patients treated with tacrolimus. It was probably associated with higher expression of MMP-2, TIMP-2 and collagen in the transplanted organ [66].

Fibrosis remains the serious problem in aspect of immunosuppressive treatment. The therapy with the 
application of pirfenidone- antifibrotic compound probably inhibits the processes leading to fibrosis. In the study which examines the inhibitory effect of pirfenidone on the expression of profibrotic genes in the nephrotoxicity induced by tacrolimus model, the application of sole inhibitor was compared with the therapy based on pirfenidone. Decrease of TIMP-1 expression and lack of effect on the expression of collagen, MMP-2 and MMP-9 in the rats kidneys were reported in monotherapy, whereas, two drugs resulted in the higher decrease of TIMP-1 and collagen expression [67].

Another widely applied group of immunosuppressants are mTOR pathway inhibitors. mTOR protein is threonine-serine kinase, the major task of which is maintaining control on proliferation, growth and motion of cells. Rapamycin inhibits mTOR pathway by interacting with FKPB-12 receptor [3]. It prevents the translation of proteins involved in the cellular cycle progression: $\mathrm{T}$ - and B-lymphocytes remain in G1 phase [3, 4]. Antiproliferation activity of rapamycin is also applied in cardiology. Inhibition of division and migration of smooth myocytes positively affects remote test results among the patients who underwent angioplasty of the coronary arteries. Stents coated with rapamycin prevent restenosis much more effectively than the classic ones [4].

In the study of Waller et al. [61] on the influence of immunosuppressants on the rats arteries, rapamycin turned out to exhibit the lowest level of toxicity. Despite similar expression level of MMP-2, MMP-9, TIMP-1 and ECM accumulation, it was the only drug which did not cause the thickening of the tunica intima of the wall of aorta. The depositing of the ECM was less marked in case of the application of rapamycinwall in contrast to the vessel walls among the animals treated with CsA [61]. Additionally, rapamycin displays inhibitory effect on cell migration activity, what was described by Gao et al. [68]. The results of the aforementioned study suggest that rapamycin inhibits cell migration and ECM degradation by inhibiting endothelial-tomesenchymal transition and the endothelial cell secretion of MMP-2 and MMP-9. These processes may be related to possible mechanisms for the inhibition of angiogenesis by rapamycin [68].

The inhibitory impact of rapamycin on the reconstruction of vessels and expression of genes associated with the fibrosis in the model of transplantation of the aortas of rats was also observed [69]. The ascending segment of the thoracic aorta taken from the $\mathrm{f} 344$ rats was transplanted to the Lewis rats for the anastomosis with the abdominal aorta to make a loop. After the surgery, the animals were treated with rapamycin in two doses 0.25 $\mathrm{mg} / \mathrm{kg} /$ daily and $0.5 \mathrm{mg} / \mathrm{kg} /$ daily. The application of higher dose did not cause hyperplasia of the intima membrane, it inhibited depositing of the ECM and did not display expansive restructuring of the vessels in comparison to the control groups. The decrease of the MMP-2, MMP-9 collagen III and TMP-1 expression was noticed. Lower effect of the drug effect on the restructuring of the vessels was observed among the animals treated with lower dose, which resulted in bigger inflammatory lesion and increased expression of MMP-9. It suggests that rapamycin may have profound influence on the inhibition of remodeling of the vessels which have been damaged. It is of great importance then to administer properly selected dosage which will stop the accumulation of the inflammatory process and thus remodeling [69].

Furthermore, in the studies on aneurysm of aorta, inhibitory effect of rapamycin on the progression of change was observed. The rats which were given rapamycin presented $40 \%$ decrease of aneurism progression in comparison to the control group. Interestingly, much lower MMP-9 activity among the rats subjected to mTORs was reported [70].

\section{Conclusions}

Due to the fact that the properties of immunosuppressive drugs still remain unclear and transplant recipients need to use these medicines every day, knowledge of this should be further expanded. The deceases of the patients with the functioning graft who were diagnosed with the cardiovascular system diseases, constitute $50 \%$ of all renal transplant recipients. Immunosuppressive treatment leads to many pathological alterations within the organs and tissues and additionally they undoubtedly affect the activity of MMPs in the wall of the vessels.

\section{Competing Interests}

The authors have declared that no competing interest exists.

\section{References}

1. Wilk A, Szypulska-Koziarska D, Kedzierska-Kapuza K, Kolasa-Wolosiuk A, Misiakiewicz-Has K, Ciechanowski $K$, et al. Effect of long-term immunosuppressive therapy on native rat liver morphology and hepatocyteapoptosis. Transpl Immunol. 2018; 50: 1-7.

2. Colombo D, Ammirati E. Cyclosporine in transplantation - a history of converging timelines. Journal of biological regulators and homeostatic agents. 2011; 25: 493-504.

3. Edyta Ulińska AUMM. Aspekty kliniczne znaczenia kinazy mTOR w patogenezie ostrej białaczki limfoblastycznej u dzieci. Aspekty kliniczne znaczenia kinazy mTOR $\mathrm{w}$ patogenezie ostrej białaczki limfoblastycznej $\mathrm{u}$ dzieci. 2015; 8: 43-8--8.

4. Osiecka K, Imko-Walczuk B, Lizakowski S, Dębska-Ślizień A, Rutkowski B. Zastosowanie inhibitorów mTOR w wybranych schorzeniach dermatologicznych. Dermatology Review/Przegląd Dermatologiczny. 2011; 98: 524-8.

5. Osiecki M, Woźniak M, Kierkuś J. Zastosowanie cyklosporyny A we wrzodziejącym zapaleniu jelita grubego i autoimmunizacyjnym zapaleniu wątroby u dzieci. Pediatria Polska. 2016; 91: 46-51. 
6. Tedesco D, Haragsim L. Cyclosporine: a review. Journal of transplantation. 2012; 2012: 230386

7. Guan TW, Lin YJ, Ou MY, Chen KB. Efficacy and safety of everolimus treatment on liver transplant recipients: a meta-analysis. Eur J Clin Invest. 2019; p: e13179.

8. Hoorn EJ, Walsh SB, McCormick JA, Zietse R, Unwin RJ, Ellison DH. Pathogenesis of calcineurin inhibitor-induced hypertension. J Nephrol. 2012; 25: 269-75.

9. Sakuma K, Yamaguchi A. The functional role of calcineurin in hypertrophy, regeneration, and disorders of skeletal muscle. Journal of biomedicine \& biotechnology. 2010; 2010: 721219 .

10. Solez K, Colvin RB, Racusen LC, Sis B, Halloran PF, Birk PE, et al. Banff '05 Meeting Report: differential diagnosis of chronic allograft injury and elimination of chronic allograft nephropathy ('CAN'). Am J Transplant. United States; 2007; p: 518-26.

11. Theocharis AD, Skandalis SS, Gialeli C, Karamanos NK. Extracellular matrix structure. Adv Drug Deliv Rev. 2016; 97: 4-27.

12. Krzyzanowska-Golab D, Lemanska-Perek A, Katnik-Prastowska I. [Fibronectin as an active component of the extracellular matrix]. Postepy Hig Med Dosw (Online). 2007; 61: 655-63.

13. Papazafiropoulou A, Tentolouris N. Matrix metalloproteinases and cardiovascular diseases. Hippokratia. 2009; 13: 76-82.

14. Bonnans C, Chou J, Werb Z. Remodelling the extracellular matrix in development and disease. Nat Rev Mol Cell Biol. 2014; 15: 786-801.

15. Lipka D, Boratynski J. [Metalloproteinases. Structure and function]. Postepy Hig Med Dosw (Online). 2008; 62: 328-36.

16. Zitka O, Kukacka J, Krizkova S, Huska D, Adam V, Masarik M, et al. Matrix metalloproteinases. Current medicinal chemistry. 2010; 17: 3751-68.

17. Liu B, Ma J, Zhu Y. [Advances in the research of extracellular matrix protein prediction tools]. Sheng Wu Gong Cheng Xue Bao. 2019; 35: 1571-80.

18. Humphrey JD, Dufresne ER, Schwartz MA. Mechanotransduction and extracellular matrix homeostasis. Nat Rev Mol Cell Biol. 2014; 15: 802-12.

19. Myasoedova VA, Chistiakov DA, Grechko AV, Orekhov AN. Matrix metalloproteinases in pro-atherosclerotic arterial remodeling. J Mol Cell Cardiol. 2018; 123: 159-67.

20. Kular JK, Basu S, Sharma RI. The extracellular matrix: Structure, composition, age-related differences, tools for analysis and applications for tissue engineering. J Tissue Eng. 2014; 5: 2041731414557112.

21. Halper J. Basic Components of Vascular Connective Tissue and Extracellular Matrix. Adv Pharmacol. 2018; 81: 95-127.

22. Raffetto JD, Khalil RA. Matrix metalloproteinases and their inhibitors in vascular remodeling and vascular disease. Biochemical pharmacology. 2008; 75: 346-59.

23. Wang X, Khalil RA. Matrix Metalloproteinases, Vascular Remodeling, and Vascular Disease. Adv Pharmacol. 2018; 81: 241-330.

24. Kapoor C, Vaidya S, Wadhwan V, Kaur G, Pathak A. Seesaw of matrix metalloproteinases (MMPs). J Cancer Res Ther. 2016; 12: 28-35.

25. Daniele A, Abbate I, Oakley C, Casamassima P, Savino E, Casamassima A, et al. Clinical and prognostic role of matrix metalloproteinase-2, -9 and their inhibitors in breast cancer and liver diseases: A review. Int J Biochem Cell Biol. 2016; 77: 91-101.

26. Fic P, Zakrocka I, Kurzepa J, Stepulak A. [Matrix metalloproteinases and atherosclerosis]. Postepy Hig Med Dosw (Online). 2011; 65: 16-27.

27. Sampieri C, Orozco-Ortega R. Matrix metalloproteinases and tissue inhibitors of metalloproteinases in chronic kidney disease and acute kidney injury: a systematic review of the literature. Hippokratia; 2018; p: 99-104.

28. Sabir N, Hussain T, Mangi MH, Zhao D, Zhou X. Matrix metalloproteinases: Expression, regulation and role in the immunopathology of tuberculosis. Cell Prolif. 2019; 52: e12649.

29. Sieminska-Kuczer A, Vertyporokh L, Andrejko M, Wojda I, Staczek S, Zdybicka-Barabas A, et al. [Metalloproteases and their inhibitors: role in pathogenesis of selected examples]. Postepy Biochem. 2017; 63: 269-76.

30. Brew K. Reflections on the evolution of the vertebrate tissue inhibitors of metalloproteinases. Faseb j. 2019; 33: 71-87.

31. Zakiyanov O, Kalousova M, Zima T, Tesar V. Matrix Metalloproteinases in Renal Diseases: A Critical Appraisal. Kidney Blood Press Res. 2019; 44: 298-330

32. Hannocks MJ, Zhang X, Gerwien H, Chashchina A, Burmeister M, Korpos E, et al. The gelatinases, MMP-2 and MMP-9, as fine tuners of neuroinflammatory processes. Matrix Biol. 2019; 75-76: 102-13.

33. Naim A, Pan Q, Baig MS. Matrix Metalloproteinases (MMPs) in Liver Diseases. J Clin Exp Hepatol. 2017; 7: 367-72.

34. Olszyński K, Zimowska M. Budowa i funkcja metaloproteinaz macierzy zewnątrzkomórkowej. Post Bioch. 2009; 55: 7684

35. Wysocka A, Gizinski S, Lechowski R. Metaloproteinazy macierzy-ich struktura oraz znaczenie. Życie Weterynaryjne. 2014; 89.

36. Kuna J, Kuna A, Dziedzic M, Grafka A, Łopucki M, Pęksa B, et al. Rola metaloproteinaz macierzy zewnatrzkomórkowej w mechanizmach uszkodzeń narzadowych w przebiegu sepsy. Diagnostyka Laboratoryjna. 2015; 51

37. Jarvelainen H, Sainio A, Koulu M, Wight TN, Penttinen R. Extracellular matrix molecules: potential targets in pharmacotherapy. Pharmacological reviews. 2009; 61: 198-223.

38. Rohani MG, Parks WC. Matrix remodeling by MMPs during wound repair. Matrix Biol. 2015; 44-46: 113-21.
39. Seifert R, Kuhlmann MT, Eligehausen S, Kiefer F, Hermann S, Schafers M Molecular imaging of MMP activity discriminates unstable from stable plaque phenotypes in shear-stress induced murine atherosclerosis. PLoS One. 2018; 13: $\mathrm{e} 0204305$.

40. Alameddine HS, Morgan JE. Matrix Metalloproteinases and Tissue Inhibitor of Metalloproteinases in Inflammation and Fibrosis of Skeletal Muscles. J Neuromuscul Dis. 2016; 3: 455-73.

41. Tokuhara CK, Santesso MR, Oliveira GSN, Ventura T, Doyama JT, Zambuzzi $W F$, et al. Updating the role of matrix metalloproteinases in mineralized tissue and related diseases. J Appl Oral Sci. 2019; 27: e20180596.

42. Ketelhuth DF, Back M. The role of matrix metalloproteinases in atherothrombosis. Curr Atheroscler Rep. 2011; 13: 162-9.

43. Li X. Gelatinase inhibitors: a patent review (2011-2017). Expert Opin Ther Pat. 2018; 28: 31-46

44. Fic P, Zakrocka I, Kurzepa J, Stepulak A, Otolaryngologii O. Metaloproteinazy w miażdżycy naczyń krwionośnych Matrix metalloproteinases and atherosclerosis. Postepy Hig Med Dosw (Online). 2011; 65: 16-27.

45. Inoue T, Kato T, Takayanagi $\mathrm{K}$, Uchida T, Yaguchi I, Kamishirado H, et al. Circulating matrix metalloproteinase- 1 and -3 in patients with an acute coronary syndrome. The American Journal of Cardiology. 2003; 92: 1461-4.

46. Siefert SA, Sarkar R. Matrix metalloproteinases in vascular physiology and disease. Vascular. 2012; 20: 210-6.

47. Turu MM, Krupinski J, Catena E, Rosell A, Montaner J, Rubio F, et al. Intraplaque MMP-8 levels are increased in asymptomatic patients with carotid plaque progression on ultrasound. Atherosclerosis. 2006; 187: 161-9.

48. Alvarez B, Ruiz C, Chacón P, Alvarez-Sabin J, Matas M. Serum values of metalloproteinase- 2 and metalloproteinase- 9 as related to unstable plaque and inflammatory cells in patients with greater than $70 \%$ carotid artery stenosis. Journal of Vascular Surgery. 2004; 40: 469-75.

49. Kai H, Ikeda H, Yasukawa H, Kai M, Seki Y, Kuwahara F, et al. Peripheral blood levels of matrix metalloproteases-2 and -9 are elevated in patients with acute coronary syndromes. Journal of the American College of Cardiology. 1998; 32: 368.

50. Derosa G, D'Angelo A, Ciccarelli L, Piccinni MN, Pricolo F, Salvadeo S, et al. Matrix Metalloproteinase-2, -9 , and Tissue Inhibitor of Metalloproteinase-1 in Patients with Hypertension. Endothelium. 2006; 13: 227-31.

51. Trojanek J. Rola metaloproteinaz macierzy zewnątrzkomórkowej i tkankowych inhibitorów metaloproteinaz w nadciśnieniu tetniczym. Patogeneza nadciśnienia a problem otyłości. Post Biochem. 2015; 61: 356-63.

52. Yasmin, McEniery CM, Wallace S, Dakham Z, Pulsalkar P, Maki-Petaja K, et al. Matrix metalloproteinase-9 (MMP-9), MMP-2, and serum elastase activity are associated with systolic hypertension and arterial stiffness. Arteriosclerosis, thrombosis, and vascular biology. 2005; 25: 372

53. Skóra J, Pupka A, Barć P, Dawiskiba T. Aktywność metaloproteinaz w ścianie tetniaka aorty brzusznej. Puls Uczelni. 2012; p: 7-10.

54. Tengiz I, Ercan E, Aliyev E, Sekuri C, Duman C, Altuglu I. Elevated levels of matrix metalloprotein-3 in patients with coronary aneurysm: A case control study. Curr Control Trials Cardiovasc Med. 2004; 5: 10-

55. Busti C, Falcinelli E, Momi S, Gresele P. Matrix metalloproteinases and peripheral arterial disease. Internal and emergency medicine. 2010; 5: 13-25.

56. Klee CB, Ren H, Wang X. Regulation of the calmodulin-stimulated protein phosphatase, calcineurin. J Biol Chem. 1998; 273: 13367-70.

57. Mok CC. Calcineurin inhibitors in systemic lupus erythematosus. Best Pract Res Clin Rheumatol. 2017; 31: 429-38.

58. Hoorn EJ, Walsh SB, McCormick JA, Zietse R, Unwin RJ, Ellison DH. Pathogenesis of calcineurin inhibitor-induced hypertension. J Nephrol. 2012; 25: 269-75.

59. Chakkera HA, Kudva Y, Kaplan B. Calcineurin Inhibitors: Pharmacologic Mechanisms Impacting Both Insulin Resistance and Insulin Secretion Leading to Glucose Dysregulation and Diabetes Mellitus. Clin Pharmacol Ther. 2017; 101: $114-20$

60. Ha E, Mun KC. Effects of Cyclosporine on Metalloproteinase in Endothelial Cells. Transplantation Proceedings. 2012; 44: 991-2.

61. Waller JR, Brook NR, Bicknell GR, Nicholson ML. Differential effects of modern immunosuppressive agents on the development of intimal hyperplasia. Transplant international : official journal of the European Society for Organ Transplantation. 2004; 17: 9-14.

62. Bianchi R, Rodella L, Rezzani R. Cyclosporine A up-regulates expression of matrix metalloproteinase 2 and vascular endothelial growth factor in rat heart. International immunopharmacology. 2003; 3: 427-33.

63. Alfarano C, Roubeix C, Chaaya R, Ceccaldi C, Calise D, Mias C, et al. Intraparenchymal injection of bone marrow mesenchymal stem cells reduces kidney fibrosis after ischemia-reperfusion in cyclosporine-immunosuppressed rats. Cell transplantation. 2012; 21: 2009-19.

64. Trandinh CC, Pao GM, Saier MH, Jr. Structural and evolutionary relationships among the immunophilins: two ubiquitous families of peptidyl-prolyl cis-trans isomerases. Faseb j. 1992; 6: 3410-20.

65. Bicknell GR, Williams ST, Shaw JA, Pringle JH, Furness PN, Nicholson ML. Differential effects of cyclosporin and tacrolimus on the expression of fibrosis-associated genes in isolated glomeruli from renal transplants. The British journal of surgery. 2000; 87: 1569-75.

66. Khanna A, Plummer M, Bromberek C, Bresnahan B, Hariharan S. Expression of TGF-beta and fibrogenic genes in transplant recipients with tacrolimus and cyclosporine nephrotoxicity. Kidney international. 2002; 62: 2257-63. 
67. Brook NR, Waller JR, Bicknell GR, Nicholson ML. The experimental agent pirfenidone reduces pro-fibrotic gene expression in a model of tacrolimus-induced nephrotoxicity. The Journal of surgical research. 2005; 125: 137-43.

68. Gao H, Zhang J, Liu T, Shi W. Rapamycin prevents endothelial cell migration by inhibiting the endothelial-to-mesenchymal transition and matrix metalloproteinase-2 and -9: an in vitro study. Mol Vis. 2011; 17: 3406-14.

69. Murphy GJ, Bicknell GR, Nicholson ML. Rapamycin inhibits vascular remodeling in an experimental model of allograft vasculopathy and attenuates associated changes in fibrosis-associated gene expression. The Journal of heart and lung transplantation : the official publication of the International Society for Heart Transplantation. 2003; 22: 533-41.

70. Lawrence DM, Singh RS, Franklin DP, Carey DJ, Elmore JR. Rapamycin suppresses experimental aortic aneurysm growth. Journal of Vascular Surgery. 2004; 40: 334-8. 